\title{
Soil Erosion Control on Arable Lands from North-East Romania
}

\author{
Bucur Daniel, Jitareanu Gerard and Ailincai Costica \\ University of Agricultural Sciences and Veterinary Medicine in Iasi \\ Romania
}

\section{Introduction}

Since the beginning of its formation, the crust of the Earth has evolved under the action of the morphogenetic processes occurring differently as periodicity and intensity as a result of the interacting processes that change the surface of the earth at the levels of interference of the lithosphere with the atmosphere, hydrosphere and biosphere.

As part of the exogenous morphogenetic processes, soil erosion plays an important role in the dynamics that shape the crust of the Earth. Erosion is the process by which soil or rock particles detach themselves from the land surface, being carried from their place of origin and deposited elsewhere (Selby, 1993).

The three stages of natural erosion are performed by two main agents: water and air in motion, whose inexhaustible kinetic sources are solar energy and gravity.

Soil tillage using tools also makes the human factor an erosional agent because the three phases of erosion can be distinguished in this activity. Unlike other soil erosion agents, human activity can be directly controlled and rationally directed.

Soil erosion is one of the main causes of vast agricultural and forest degradation on the Earth.

In Romania, the theoretical and applied study of water erosion is of particular concern as the physical and geographical conditions of the greater part of the territory are influenced by this process.

About one third (i.e. 4918.8 thou ha) of the total area of agricultural lands is affected by erosion and landslides.

Among the agricultural uses, orchards are the most severely affected (65.6\%), followed by natural grasslands (58.3\%); the arable surface and landslides is about $20 \%$ of the total use category.

Soil erosion prevention and control still prevails on arable land as there are approximately 2.6 million hectares (i.e. $26 \%$ of the total arable land) whose slope is greater than $5 \%$.

On the sloping lands where there are potential conditions for increased erosion, the first goal of the anti-erosion action is to reduce the annual loss to levels that can be compensated by the natural process of soil recovery.

In Romania, for the arable lands consisting of medium soils, the annual admissible erosion is considered $6 \mathrm{t} \cdot \mathrm{ha}^{-1} \cdot$ year $^{-1}$.

The decrease in the annual soil loss favours the preservation of nutrients and rain water retention, thus improving soil fertility of the sloping lands. 
There are other important and inexpensive measures that can be taken for the sloping arable lands in order to maintain the soil losses within allowable limits: crop structure and rotation, crops location on the slope, soil tillage and fertilization.

Crops structure. Different plant combinations should be grown on the sloping arable lands in order to prevent erosion to exceed the limit. Research performed under various conditions allowed the calculation the best rate between the rows crops in the crop structure so that soil loss is maintained within tolerable limits. Thus, on an arable land with a slope of $10-12 \%$ and a loamy-clay soil in northern Moldavian Plateau, the annual soil loss was below 6 t.ha-1 at the highest rate of $62 \%$ row crops of the assortment of cultivated plants.

Crops emplacement on the slopes. For soil, water and nutrients loss to be insignificant, the selection of the appropriate range of plants to be grown on sloping arable land and their allocation within rational rotation should be associated with special systems for the location of plants growing on the slopes.

Strip cultivation and cover crop cultivation are the most frequently used anti-erosion systems.

Contour and strip cropping is a simple, effective and convenient system to control soil erosion on the arable land with slopes greater than 5-6\%. It consists of cultivation on the slope, parallel to the level curves row crops on land strips alternating with the best protective plants (winter grains, annual legumes, etc.). Thus, the kinetic energy of the water runoffs along the width of strips grown with row crops is dissipated in the downstream area which is grown with crops planted in dense rows.

The control of surface runoff and the reduced erosion intensity depend on the width of the cultivated strips, which in turn depends on the slope, soil erosion susceptibility, rainfall aggression, etc. Determining the indicative value of the strip width can be made by using empirical relationships based on either the critical erosion velocity criterion, or the annually averaged admissible erosion.

Considering the admissible erosion of $6 \mathrm{t}^{\mathrm{t}}$ ha ${ }^{-1}$.year ${ }^{-1}$, the values regarding the strip width are presented in Table 1.

\begin{tabular}{|c|c|c|c|}
\hline \multirow{2}{*}{$\begin{array}{c}\text { Slope } \\
(\%)\end{array}$} & \multicolumn{3}{|c|}{ Strip width for the soil with erodability: } \\
\cline { 2 - 4 } & low & medium & high \\
\hline $5-10$ & $117-83$ & $100-71$ & $79-56$ \\
\hline $11-15$ & $78-59$ & $66-50$ & $52-40$ \\
\hline $16-25$ & $55-30$ & $47-25$ & $37-20$ \\
\hline
\end{tabular}

Table 1. Indicative values of cultivated strips width $(\mathrm{m})$, depending on slope and soil resistance to erosion

The results of the research carried out at the Perieni Research and Development Centre for Soil Erosion Control emphasize that, irrespective of slope size, soil erosion decreases by 2 - 8 times in the strip planting system, compared with a maize-only crop grown on the slope (Table 2).

There was no significant yield increase in the early years of applying the strip planting system; however, as erosion decreased, the effects were cumulative and production increased significantly.

The location of the planted strips remained unchanged and, after 5-6 years, uneven forms occurred at the boundary between the consecutive strips which, if properly cultivated with grass and maintained, can become slopes agricultural terraces. 


\begin{tabular}{|c|c|c|c|}
\hline \multirow{2}{*}{ Slope (\%) } & Crop and strip width $(\mathrm{m})$ & \multicolumn{2}{|c|}{ Eroded soil } \\
\cline { 2 - 4 } & & $\mathrm{t} / \mathrm{ha}$ & $\%$ \\
\hline \multirow{5}{*}{12} & Wheat + maize $4 \times 40$ & 25,9 & 28,6 \\
\cline { 2 - 4 } & Wheat + maize $2 \times 80$ & 35,6 & 39,4 \\
\cline { 2 - 4 } & Wheat $120+$ maize 40 & 15,6 & 17,2 \\
\cline { 2 - 4 } & Maize $120+$ wheat 40 & 63,3 & 69,7 \\
\cline { 2 - 4 } & Wheat 160 & 5,8 & 6,4 \\
\hline \multirow{3}{*}{$14-16$} & Maize 160 & 90,3 & 100,0 \\
\cline { 2 - 4 } & Wheat + maize 60 & 35,9 & 69,1 \\
\cline { 2 - 4 } & Wheat + maize 2x 40 & 27,2 & 52,4 \\
\cline { 2 - 4 } & Wheat 60 + maize 20 & 6,3 & 25,6 \\
\cline { 2 - 4 } & Wheat 80 & 51,9 & 13,3 \\
\hline
\end{tabular}

Table 2. Influence of strip planting system on soil erosion (data from RDCSEC Perieni)

The application of the stripe planting system is expected to result in about $8 \%$ extra work, compared with a single crop grown on the slope.

Contour buffer strips used to retain soil and reduce erosion. This type of buffer strip is simply a strip of perennial vegetation that is alternated with wider cultivated strips of cropland. Buffer strips system is recommended on arable lands with a slope greater than 8$10 \%$, especially in areas of annual rainfalls exceeding $500 \mathrm{~mm}$; however, the system can be applied successfully in dry areas as well, by selecting the appropriate grass assortment for strips sowing.

The width of land between the buffer strips is determined so that soil loss is limited to acceptable values.

The buffer strips are generally 4-6 $\mathrm{m}$ in width. Sometimes, width may increase to $8-10 \mathrm{~m}$ in the lowest third of the deep slopes with a convex profile and soils that are less resistant to erosion. Common practice uses strips whose width is equal to one or two working widths of the sowing machines employed in the area.

In case the slope surface is uneven, grass strips of variable width are recommended to achieve consistent width on the entire length of the cultivated strip between the strips, we recommend buffer strips of variable width.

The hydrological function of a grass strip is to intercept, partially detain and disperse the water runoffs from upstream. A rough grass reduces the transport capacity of the flow, and some part of the solid material carried by the water currents is discharged on the grasscovered area. Over the years, successive deposits contribute to transformation of the buffer strips into slopes of agricultural terraces provided that their location remains unchanged.

Many researchers have found positive effects of the buffer strips system of cultivation on leakage reduction and soil erosion. After twenty years of research in the Moldavian Plateau, for example, soil loss was found under the admissible limit on the protected arable areas, i.e. 3-4 times lower than on the lands with no buffer strips (Popa et al., 1984).

Better results can be obtained by applying a combination of strip and buffer strips systems. Among the advantages, there are:

- $\quad$ significant decrease in soil loss by the retention of water and eroded material both in the grass-covered strips and in the cultivated strips; 
- the width of the grown strips can increase, thus leading to increased efficiency of the agricultural machinery and decreased production expenses per surface unit;

- $\quad$ the strips planted are better delimited, as they are bordered by the grass covered strips. By applying the buffer strips system, the arable area decreases by 3-5\%; however, the loss is compensated and exceeded by the increased yield resulting from the grown strips and the hay yield obtained from the grass covered strips (3.5-4.0 $\mathrm{t} / \mathrm{ha}$ ).

Soil tillage. Of all the soil tillage works, ploughing is of the greatest interest in terms of antierosion actions. Concerning the direction, it was observed that ploughing along the steepest slope and, consequently, sowing downhill favour soil erosion to a great extent. By comparison, ploughing along the level curves helps reduce water loss by $75 \%$ and soil loss by 2-9 times. The best results were obtained when ploughing was performed with a reversible plough.

The experiments performed at the Perieni Research and Development Centre for Soil Erosion Control to determine the influence of the ploughing depth on the erosion of the arable lands points out that at moderate values of slope and medium soils with good natural drainage, increasing the ploughing depth over $20 \mathrm{~cm}$ is not justified in terms of erosion or increased yield in wheat and peas. However, in maize, ploughing at $30 \mathrm{~cm}$ depth reduced erosion by $28 \%$ while the water reserves available in the soil increased by over $300 \mathrm{~m}^{3} / \mathrm{ha}$, compared with $20 \mathrm{~cm}$ ploughing. These results prove the opportunity for deep ploughing in the hoed crops grown on the slopes.

Finally, the sloping land planting with no tillage, according to the minimum tillage or no tillage system was effective not only economically but also in terms of erosion as reducing the number of machine passes results in less soil compaction, structure destruction, and lower soil carried downstream through repeated mobilization, etc.

Fertilization of sloping arable land indirectly contributes to reducing soil loss by erosion. The rational application of fertilizers ensures a vigorous root system development and increases plant mass on the surface. Under these circumstances, water infiltration into the soil is significantly improved because the kinetic energy of the raindrops and surface runoff is reduced by enhancing the roughness created by the increasing volume of vegetation.

Sial et al. (2007) found that the average soil and humus loss in summer grains and potatoes were 3-4 times higher on the unfertilized land, compared with the fertilized variants.

The anti-erosion effect produced by the fertilization of sloping arable lands is considered higher in the plants of long vegetation time that are sown in thick rows.

In the Moldavian Plateau, located in north-eastern Romania, the relief is predominantly hilly. The average altitude is $250 \mathrm{~m}$, with dominant slopes below $20 \%$; however, there are also slopes whose geodeclivity varies between $25 \%$ and $35 \%$ or even more. The relief has evolved on complex lithological successions composed of sandy-loamy and marly rocks with intercalations of sands, sandstones and limestones.

The pedological cover is dominated by agricultural use, as types and subtypes are successive in the area - from less developed, in the East and South-East (mollisoils) to highly developed in the North-East (argiluvisoils). Here, the local soil formation factors have determined the occurrence of several insular or much elongated intrazonal areas.

The climate is temperate continental with large annual thermal amplitude; rainfalls occur mainly in the growing season and are unevenly distributed, usually as torrential rains.

Such natural conditions are favourable to slope processes, therefore it is necessary to take measures and apply works to maintain the tolerable limits of water erosion, and to contribute to the stabilization of the potential sliding surfaces in the risk areas. 


\section{Non-structural soil erosion control measures}

\subsection{Protecting the soil from erosion by cropping systems and fertilization}

Protecting the soil from erosion is the first step toward a sustainable agriculture. The major costs to the farm associated with soil erosion come from the replacement of lost nutrients and reduced water holding ability, accounting for 50 to $75 \%$ of productivity loss (Pimentel D. et al., 1995).

In all the countries, the investigations carried out in the last period have followed the establishment of some technological solutions that maintain the productivity of agroecosystem and the protection of environment factors. The Soil Protection Framework Directive of EU includes the necessary legislative proposals, taken into account by all the member states concerning the three main threats on the decline in organic matter, soil erosion and contamination and some additional aspects regarding compaction, diminution of biodiversity, floods and landslides. In the EU, more than 150 million hectares of soil are affected by erosion and $45 \%$ of the European soils have a low content of organic matter (Russell et al., 2006).

In Austria, during 1994-2007, the mean soil losses in three locations dropped from 6.1 to 1.8 $\mathrm{t} \cdot \mathrm{ha}^{-1}$, by using conservation tillage in cover crops, and until $1.0 \mathrm{t} \mathrm{ha}^{-1}$ year-1 with direct drilling. Nitrogen $\left(9.2,3.7\right.$ and $2.5 \mathrm{~kg} \mathrm{ha}^{-1}$ year $\left.^{-1}\right)$ and phosphorus $\left(4.7,1.3,0.7 \mathrm{~kg} \mathrm{ha}^{-1} \mathrm{year}^{-1}\right)$ losses showed similar tendencies (Rosner et al., 2008).

Of the total Italian area, $51.8 \%$ is considered to be at potential risk of desertification (Marchetti et al., 2008). Soil erosion is the most relevant soil degradation system that affects at least $19 \%$ of the territory at the potential risk of desertification, while aridity is the second desertification risk (19.0\%) (Moraru et al., 2010).

The Directive 2006/42/EC proposes the identification of zones with erosion-degraded soils and organic matter in decline, for meeting the requirements of the United Nations Convention to Combat Desertification (UNCCD) in Northern Mediterranean and Central and Eastern European Country Parties.

In Romania, soil erosion is the most expensive degradation process, which affects almost $63 \%$ of the total area and $56 \%$ of the arable area from Romania. Investigations on the potential erosion, conditioned by geomorphologic, soil and climatic factors, have shown that in NE Romania, the mean soil losses by erosion were of $18.3 \mathrm{t} \cdot \mathrm{ha}^{-1}$. The studies, carried out on the effective erosion, based on direct determinations and complex analyses, have shown that in the entire NE zone, the effective erosion had a mean value of $4.8 \mathrm{t} \mathrm{ha}^{-1}$ year- $^{-1}$. The north-eastern region has $15.45 \%(2,131,421 \mathrm{ha})$ of the farming area of Romania $(14,836,585$ ha) and includes huge areas with soils affected by erosion (over 60\%), acidification, compaction, landslides and other degradation forms (Bucur et al., 2007).

In Bulgaria, the investigations showed that the mean annual rate of erosion on the arable lands was $4.76 \mathrm{t}$ ha- $\mathrm{a}^{-1}$ and $2.69 \mathrm{t} \cdot \mathrm{ha}^{-1}$ on improved arable lands. Soil losses by erosion on the fields ploughed on the upstream-downstream direction, which are cultivated with maize, are $7.48 \mathrm{t} \mathrm{ha-1}$. In sunflower, cultivated with conventional tillage, the annual eroded soil was $3.044 \mathrm{tha}^{-1}$, and by wheat straw and green fertilizer incorporation into soil, erosion has decreased at $2.327 \mathrm{t}^{\mathrm{h}} \mathrm{ha}^{-1}$ and $0.937 \mathrm{t} \mathrm{ha}^{-1}$, respectively (Totka et al., 2006).

The favorable influence of reduced tillage system and of crop residues on soil erosion was also shown by other scientists (Jha et al., 2010). In no-tillage system, soil losses by erosion were close to the ones found in case of soil protection with $6 \mathrm{t}$ h ha-1 of mulch. On $8.5 \%$ slope fields from SW Finland, annual soil losses by erosion are 5- $6 \mathrm{t}$. ha $\mathrm{a}^{-1}$ and leached nitrogen and 
phosphorus amounts are 15.0 and $1.1 \mathrm{~kg}^{\mathrm{ha}}{ }^{-1}$ year-1, respectively (Muukkonen et al., 2007). The investigations conducted in Minnesota, USA, have shown that 927, 1853 and $3706 \mathrm{~kg}$. ha${ }^{1}$ year-1 of crop residues, applied in maize crops, have decreased soil erosion until 6.177, 1.730 and $0.988 \mathrm{t}^{\mathrm{t}} \mathrm{a}^{-1}$ respectively, and water runoff until 35.6, 25.4 and $22.9 \mathrm{~mm}$, respectively (Lindstrom, 1986). The results concerning erosion in the Coshocton, USA, showed that in the areas annual mean soil losses by erosion were $1.18 \mathrm{t} \mathrm{ha-1}$ (range, $0.35 \mathrm{t}$. ha1 in wheat and $7.36 \mathrm{t}$. ha-1 in maize) (Izaurralde et al., 2007).

Investigations conducted during 1980-2010 on a cambic chernozem at the Agricultural Research and Development Station of Podu- Iloaiei, Iasi County, followed the influence of different crop rotations on water runoff and nutrient losses, due to soil erosion. Experiments were conducted on the hydrographical basin of Scobalteni, with a reception area of 159 ha, a mean altitude of $119.4 \mathrm{~m}$ and a mean slope length of $250 \mathrm{~m}$. The area of the watershed has been anti-erosion set up since 1983, being used combined cropping systems made of sod rewetting and strip cultivation. The width of cultivated strips is $200-250 \mathrm{~m}$ on $5-10 \%$ slopes, $100-150 \mathrm{~m}$ on $10-15 \%$ slopes and $50-100 \mathrm{~m}$ on $15-18 \%$ slopes.

The determination of runoff and soil losses by erosion was carried out by means of loss control plots with a collecting area of $100 \mathrm{~m}^{2}(25 \mathrm{~m} \mathrm{x} 4 \mathrm{~m})$ and by means of a hydrological section equipped with spillway and limn graph and devices for sampling water and soil loss by erosion. Total nitrogen, nitrate, phosphorus and potassium contents were determined in soil and water samples, lost by erosion in different crops, thus establishing the losses of nutrient elements. The climate is temperate continental with large thermal amplitude and uneven and commonly torrential rainfall prevalent during the vegetative season. The climatic conditions in the Moldavian Plateau were characterized by a mean multiannual temperature of $9.6^{\circ} \mathrm{C}$ and a mean rainfall amount, on 80 years, of $559.2 \mathrm{~mm}$, of which 161.2 $\mathrm{mm}$ during September-December, and $398 \mathrm{~mm}$ during January-August. Within the experiment, the following rotation scheme was followed: wheat and maize continuous cropping, 2-year crop rotation (wheat-maize), 3-year crop rotation (pea-wheat-maize) and 4year crop rotation + outside field cultivated with legumes and perennial grasses (Medicago sativa + Lolium perenne).

The content of organic carbon was determined by the Walkley- Black method, to convert SOM into SOC it was multiplied by 0.58 . The content in mobile phosphorus from soil was determined by Egner-Riehm-Domingo method, in solution of ammonium acetate- lactate (AL) and potassium was measured in the same extract of acetate-lactate (AL) by flame photometry. ANOVA was used to compare the effects of treatments. In wheat, we used Gabriela variety and in maize Podu-Iloaiei 110 Hybrid.

On slope lands, soil nutrient losses being very high, due to leaching, runoff and element fixing, the establishment of rates and time of fertilizer application must be done differently, according to soil characteristics, cultural practices and climatic conditions. On eroded slope lands, the growing systems ensure the reduction in soil losses below $4 \mathrm{t}^{\text {tha }} \mathrm{a}^{-1}$ year $^{-1}$ and allow getting efficient yields from the economic point of view.

The results on water runoff and soil losses in different crops from the Moldavian Plateau, determined by control plots, have shown that, during 1980-2010, of the total amount of 570.6 $\mathrm{mm}$ rainfall, $366.7 \mathrm{~mm}(64.3 \%)$ produced water runoff, which was between $6.4 \mathrm{~mm}$ in perennial grasses, in the second year of vegetation, and $30.6-36.4 \mathrm{~mm}$, in maize and sunflower crops (Table 3). 


\begin{tabular}{|l|c|c|c|c|c|}
\hline \multicolumn{1}{|c|}{ Crop } & $\begin{array}{c}\text { Rainfall causing } \\
\text { runoff }(\mathrm{mm})\end{array}$ & $\begin{array}{c}\text { Runoff } \\
(\mathrm{mm})\end{array}$ & $\begin{array}{c}\text { Eroded } \\
\text { soil } \\
\left(\mathrm{t} \cdot \mathrm{ha}^{-1}\right)\end{array}$ & $\begin{array}{c}\text { Mean } \\
\text { turbidity } \\
\left(\mathrm{g} \cdot \mathrm{l}^{-1}\right)\end{array}$ & $\begin{array}{c}\text { Humus } \\
\left(\mathrm{kg} \cdot \mathrm{ha}^{-1}\right)\end{array}$ \\
\hline Bare fallow & 366.7 & 60.5 & 18.17 & 30.0 & 622 \\
\hline Sunflower & 366.7 & 36.4 & 8.93 & 24.5 & 310 \\
\hline I year perennial grasses & 366.7 & 19.1 & 1.91 & 10.0 & 65 \\
\hline II year perennial grasses & 289.6 & 6.4 & 0.25 & 3.8 & 8 \\
\hline Maize & 366.7 & 30.6 & 8.39 & 27.4 & 287 \\
\hline Peas & 366.7 & 21.6 & 3.72 & 17.2 & 127 \\
\hline Wheat & 337.9 & 11.5 & 1.62 & 14.1 & 56 \\
\hline Beans & 366.7 & 24.6 & 4.56 & 18.5 & 156 \\
\hline Soybean & 366.7 & 20.6 & 3.89 & 18.9 & 133 \\
\hline
\end{tabular}

* Mean annual rainfall, recorded during 1980 - 2010 - $570.6 \mathrm{~mm}$, rainfall causing runoff - $366.7 \mathrm{~mm}$

Table 3. Mean annual runoff and soil losses by erosion, recorded in different crops

The annual soil losses due to erosion, recorded at the same period, were between $0.25 \mathrm{t}$. ha${ }^{1}$ year $^{-1}$ in perennial grasses, and 8.39-8.93 $\mathrm{t} \mathrm{ha}^{-1} \mathrm{year}^{-1}$ in maize and sunflower crops. The obtained results on the potential erosion (conditioned by geo- morphological, soil and climate factors) have shown that on the fields uncovered by vegetation from the Moldavian Plateau, the mean soil losses due to erosion were $18.17 \mathrm{t} \mathrm{ha}^{-1}$, values corresponding to a moderate erosion risk. The protection degree of soil against erosion, expressed by the ratio between the value of the effective erosion (under specific technological conditions) and of the potential erosion (soil eroded under conditions of uncovered soil, which was not set up with soil erosion control works) is an indicator of erosion risk that shows soil vulnerability to erosion. It is given by the ratio between the value of the effective erosion and that of mean allowable erosion, which corresponds to soils from the studied watershed. Taking into account that the erosion process cannot be avoided and the tolerance level of soil annual

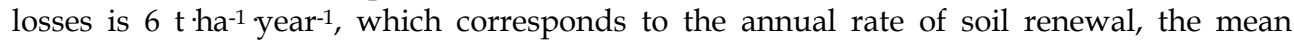
annual soil losses due to erosion, recorded during 1980-2010 in maize (8.39 $\mathrm{t} \cdot \mathrm{ha}^{-1}$ ) and sunflower $\left(8.93 \mathrm{t} \mathrm{ha}^{-1}\right)$, may result in destructing the fertile soil layer in a few decades.

Erosion has affected soil fertility by removing once with eroded soil, high amounts of organic carbon and mineral elements, which reached $16.23-17.61 \mathrm{~kg}$ ha-1 nitrogen, $1.15-1.29 \mathrm{~kg} \mathrm{ha}^{-1}$ phosphorus and 2.02-2.39 $\mathrm{kg}$ ha-1 potassium, in maize and sunflower crops (Table 4). On 16\% slope lands, the mean annual nitrogen, phosphorus and potassium leachates, due to erosion, recorded during 1980-2010, were between 9.77 and $21.29 \mathrm{~kg}^{-1} \mathrm{ha}^{-1}$ in row crops (soybean and sunflower) and between 4.48 and $9.39 \mathrm{~kg}^{\mathrm{h}} \mathrm{a}^{-1}$ in wheat and pea crops (Table 4).

The obtained results on erosion in different crop rotations have shown that under conditions of $16 \%$ slope lands from the Moldavian Plateau, the diminution in soil losses below the $4 \mathrm{t}$. ha${ }^{1}$ year-1 was done only in 3-4 year crop rotations with one or two outside fields, cultivated with perennial grasses and legumes that protect soil against erosion better (Table 5).

The results concerning water runoff, soil and mineral element losses from crops, placed in different rotations, have shown that on $16 \%$ slope lands, the use of pea-wheat-maize rotation +3 outside fields, cultivated with legumes and perennial grasses, resulted in soil losses, which diminished by $39.4 \%$ (1.98 $\left.\mathrm{t}^{\mathrm{h}} \mathrm{ha}-1\right)$, as compared to wheat-maize rotation (Table 5). On $16 \%$ slope lands, the mean annual losses of nitrogen due to erosion were comprised, during 1980-2010, between $16.23 \mathrm{~kg} \mathrm{ha}^{-1}$ in maize continuous cropping and 


\begin{tabular}{|l|c|c|c|c|c|c|c|}
\hline \multirow{2}{*}{ Crop } & \multicolumn{6}{|c|}{ Organic carbon and mineral elements lost by erosion, $\mathrm{kg}^{-1}$} \\
\cline { 2 - 9 } & $\begin{array}{c}\text { Organic } \\
\text { carbon }\end{array}$ & $\begin{array}{c}\text { N at } \\
\text { water } \\
\text { runoff }\end{array}$ & $\begin{array}{c}\text { N in eroded } \\
\text { soil }\end{array}$ & $\begin{array}{c}\text { Total } \\
\text { N }\end{array}$ & $\begin{array}{c}\text { P- } \\
\text { AL }\end{array}$ & $\begin{array}{c}\text { K- } \\
\text { AL }\end{array}$ & $\begin{array}{c}\text { Total } \\
\text { NPK }\end{array}$ \\
\hline Bare fallow & 360 & 5.397 & 25.989 & 31.386 & 2.090 & 4.362 & 37.838 \\
\hline Sunflower & 180 & 4.841 & 12.768 & 17.609 & 1.286 & 2.393 & 21.288 \\
\hline $\begin{array}{l}\text { I year perennial } \\
\text { grasses }\end{array}$ & 38 & 2.158 & 2.828 & 4.986 & 0.220 & 0.476 & 5.682 \\
\hline $\begin{array}{l}\text { II year perennial } \\
\text { grasses }\end{array}$ & 5 & 0.723 & 0.360 & 1.083 & 0.027 & 0.061 & 1.171 \\
\hline Maize & 166 & 4.315 & 11.917 & 16.232 & 1.150 & 2.022 & 19.404 \\
\hline Peas & 74 & 2.700 & 5.544 & 8.244 & 0.406 & 0.744 & 9.394 \\
\hline Wheat & 32 & 1.518 & 2.370 & 3.888 & 0.182 & 0.406 & 4.476 \\
\hline Beans & 91 & 3.247 & 6.653 & 9.900 & 0.501 & 0.911 & 11.312 \\
\hline Soybean & 77 & 2.802 & 5.679 & 8.481 & 0.443 & 0.848 & 9.772 \\
\hline
\end{tabular}

Table 4. Mean water runoff, soil, organic carbon and mineral element losses, due to erosion, in the Moldavian Plateau

\begin{tabular}{|l|c|c|c|c|c|c|}
\hline \multirow{2}{*}{ Crop rotation } & \multicolumn{2}{|l|}{ Water Runoff } & \multicolumn{2}{|c|}{ Erosion } & $\begin{array}{c}\text { Organic } \\
\text { carbon kg.ha-1 }-1\end{array}$ & $\begin{array}{c}\text { Row plants } \\
\%\end{array}$ \\
\cline { 2 - 5 } & $\mathrm{mm}$ & $\%$ & t.ha-1.year & $\%$ & $\%$ & 100 \\
\hline Mcc * & 30.6 & 100 & 8.39 & 100 & 166 & 60 \\
\hline B W M Sf W & 22.9 & 75 & 5.01 & 60 & 100 & 50 \\
\hline W M & 21.1 & 69 & 5.03 & 60 & 99 & 40 \\
\hline P W M Sf + G & 21.9 & 72 & 4.67 & 56 & 93 & 33 \\
\hline P W M & 21.2 & 69 & 4.58 & 55 & 91 & 33 \\
\hline P W M Sf + 2 G & 19.9 & 65 & 3.99 & 48 & 80 & 40 \\
\hline B W M + 2 G & 17.1 & 56 & 3.60 & 43 & 63 & 20 \\
\hline P W Sf + 2 G & 17.7 & 58 & 3.18 & 38 & 62 & 40 \\
\hline S W M + G & 16.3 & 53 & 3.12 & 37 & 60 & 17 \\
\hline P W M + 3 G & 15.4 & 50 & 3.05 & 36 & 52 & \\
\hline
\end{tabular}

* Mcc= Maize continuous cropping, B W Sf M W = Beans-wheat-sunflower-maize-wheat rotation, $\mathrm{W}$ $M=$ Wheat-maize rotation, $P$ W M= Peas-wheat-maize, $P$ W M Sf $+G=$ Peas-wheat-maize -sunflower + reserve field, with legumes and perennial grasses, $B W M+2 G=$ Beans-wheat-maize +2 reserve field, with legumes and perennial grasses, S W M = Soybean- wheat-maize +2 reserve field, with legumes and perennial grasses

Table 5. Average annual water and soil runoff by erosion in different crops rotation

$5.757 \mathrm{~kg}$ ha $^{-1}$ year-1 in pea - wheat - maize rotation + three outside fields cultivated with perennial grasses (Table 6). If phosphorus and potassium losses are low (1.15-2.02 kg ha1 year-1), the nitrogen losses should be diminished by using rotations with crop structures that protect soil against erosion.

The highest losses of nutrients were recorded in bean-wheat- sunflower-maize-wheat rotation (10.304 kg ha-1 nitrogen and $12.192 \mathrm{~kg}^{-1} \mathrm{k}^{-1}$ total NPK) (Table 6). These amounts decreased very much at the same time with the increase in the rotation structure of cover crops, such as pea, wheat, alfalfa and perennial grasses. Data are very important for 
establishing and regulating the fertilizer rates applied in crops and for controlling the environment pollution with nitrogen, phosphorus and potassium. During 1980-2010, the use of crop rotations until $20 \%$ of row plants, which also included outside fields cultivated with perennial grasses, reduced soil and mineral element losses by $36.7 \%\left(1.85 \mathrm{t}^{\mathrm{h}}\right.$ ha $\left.{ }^{-1}\right)$ and $33.7 \%$ (3.987 kg ha-1), respectively, as compared to 2-year crop rotation (wheat- maize). On 16\% slope lands during 1980-2010, the crop structure which reduced mean soil losses by erosion until $3.12 \mathrm{t}$. ha $\mathrm{a}^{-1}$ year-1 $^{-1}$ included $20 \%$ straw cereals, $20 \%$ annual legumes, $20 \%$ row crops and $40 \%$ perennial grasses and legumes.

\begin{tabular}{|l|c|c|c|c|c|c|}
\hline Crop rotations & $\begin{array}{c}\text { N at water } \\
\text { runoff }\end{array}$ & $\begin{array}{c}\text { N in eroded } \\
\text { soil }\end{array}$ & Total N & P-AL & K-AL & Total NPK \\
\hline Mcc $^{*}$ & 4.315 & 11.917 & 16.232 & 1.150 & 2.022 & 19.404 \\
\hline B W MSf W & 3.088 & 7.216 & 10.304 & 0.660 & 1.228 & 12.192 \\
\hline W M & 2.917 & 7.144 & 10.061 & 0.666 & 1.214 & 11.941 \\
\hline P W M Sf + G & 2.891 & 6.715 & 9.606 & 0.621 & 1.146 & 11.373 \\
\hline P W M & 2.844 & 6.610 & 9.454 & 0.579 & 1.057 & 11.090 \\
\hline P W M Sf + 2 G & 2.590 & 5.759 & 8.349 & 0.531 & 0.983 & 9.863 \\
\hline B W M+ 2 G & 2.249 & 4.579 & 6.828 & 0.399 & 0.734 & 7.961 \\
\hline P W Sf + 2 G & 2.245 & 4.527 & 6.772 & 0.407 & 0.775 & 7.954 \\
\hline S W M+ 2 G & 2.160 & 4.384 & 6.544 & 0.387 & 0.721 & 7.652 \\
\hline P W M + 3 G & 1.963 & 3.794 & 5.757 & 0.330 & 0.611 & 6.698 \\
\hline
\end{tabular}

Table 6. Average mineral elements lost by erosion $\left(\mathrm{kg} \cdot \mathrm{ha}^{-1}\right)$ in different crops rotations

During 1980-2010, on 16\% slope fields, the increase from 20 to $40 \%$ of row crops (maize and sunflower) used in rotations increased mean annual losses of eroded soil by $46.7 \%(1.486$ $\left.t \cdot a^{-1}\right)$ and the use of crop rotations with $60 \%$ row crops increased by $57.5 \%\left(1.829 t \cdot h^{-1}\right)$ mean annual quantities of eroded soil. According to these results concerning the contribution of melioration plants to the diminution of soil and mineral element losses due to erosion, the technical elements were established for anti-erosion works, such as width of cultivated strips and sod rewetting, crop structure, crop rotations and assortment of legumes and perennial grasses used on slope lands. This scientific information is a source for creating a database necessary for the elaboration of land improvement projects, watershed setting up and protecting soil and water resources.

The crop rotation is also important under conditions of an intensive technology, being the main measure for soil protection, crop and efficient capitalization of all technological factors. The investigations conducted in long-term experiments at Rothamsted have shown that only at high fertilizer rates $\left(>\mathrm{N}_{192} \mathrm{P}_{35} \mathrm{~K}_{90} \mathrm{Mg}_{35}\right)$, a significant increase was found in total organic carbon and stable carbon in soil ${ }^{1}$. In clayey-loam mollisol from Kanawha, the organic carbon increased from 33.3 to $37.3 \mathrm{~g} \mathrm{~kg}^{-1}$ soil, when using the rate of $270 \mathrm{~kg}^{\text {ha-1 }}$ nitrogen against the unfertilized control, only in maize-oats-alfalfa-alfalfa rotation ( $\mathrm{Li}$ et al., 2009).

On soils from the Moldavian Plateau, most of them situated on slope fields, poor in organic matter and nutrients, the proper use of different organic resources may replace a part of rich technological consumption (mineral nutrients), determine the improvement in the content of organic matter from soil and ensure better conditions for the valorisation of nitrogen fertilizers. Crop rotations with annual and perennial grasses and legumes have increased the biodiversity of agro-ecosystems, diminished the quantity of nitrogen-based fertilizers, contributed to the increase in soil fertility and diversified the options of farming management. 
The total carbon from cambic chernozem in the Moldavian Plain significantly increased at higher fertilization rates than $\mathrm{N}_{160} \mathrm{P}_{100}$, in case of organic and mineral fertilization and in 4year crop rotation, which included ameliorative perennial grasses and legumes (Table 7).

\begin{tabular}{|c|c|c|c|c|c|c|}
\hline Treatment & Mcc & W M & $\begin{array}{c}\text { PW } \\
\text { M }\end{array}$ & $\begin{array}{c}\mathrm{PW} \mathrm{MSf}+ \\
\text { G }\end{array}$ & Average & Difference \\
\hline $\mathrm{N}_{0} \mathrm{P}_{0}$ & 15.0 & 15.2 & 16.5 & 16.8 & 15.9 & 0 \\
\hline $\mathrm{N}_{80} \mathrm{P}_{60}$ & 15.5 & 14.8 & 16.9 & 17.1 & 16.1 & 0.1 \\
\hline $\mathrm{N}_{120} \mathrm{P}_{80}$ & 15.8 & 16.2 & 17.3 & 18.2 & 16.9 & 0.9 \\
\hline $\mathrm{N}_{160} \mathrm{P}_{100}$ & 16.8 & 17.0 & 18.5 & 19.7 & 18.0 & $1.9^{x}$ \\
\hline $\begin{array}{l}\mathrm{N}_{80} \mathrm{P}_{60}+30 \text { t.ha }-1 \\
\text { manure }\end{array}$ & 19.0 & 19.0 & 20.1 & 21.4 & 19.9 & $3.9^{x x x}$ \\
\hline Average & 16.4 & 16.4 & 17.9 & 18.6 & 17.3 & \\
\hline Difference & 0 & 0.0 & $1.5^{x}$ & $2.2^{x x}$ & & \\
\hline & \multicolumn{2}{|c|}{$\begin{array}{c}\text { Crop } \\
\text { rotation }\end{array}$} & \multicolumn{2}{|c|}{ Fertilizer } & \multicolumn{2}{|c|}{ Interaction } \\
\hline LSD 5\% & \multicolumn{2}{|c|}{1.4} & \multicolumn{2}{|r|}{1.5} & \multicolumn{2}{|c|}{$1.2 \mathrm{~g} \cdot \mathrm{kg}^{-1}$} \\
\hline LSD 1\% & \multicolumn{2}{|c|}{1.8} & \multicolumn{2}{|r|}{2.1} & \multicolumn{2}{|c|}{$1.6 \mathrm{~g} \cdot \mathrm{kg}^{-1}$} \\
\hline LSD $0.1 \%$ & \multicolumn{2}{|c|}{2.4} & \multicolumn{2}{|r|}{2.7} & \multicolumn{2}{|c|}{$2.1 \mathrm{~g} \cdot \mathrm{kg}^{-1}$} \\
\hline
\end{tabular}

Table 7. Influence of long-term fertilization and crop rotation on mass of carbon from soil (C, $\left.\mathrm{g} \cdot \mathrm{kg}^{-1}\right)$

In maize continuous cropping and wheat-maize rotation, very significant values of the carbon content were found only in the organic and mineral fertilization, in 4-year crop rotation + reserve field, cultivated with perennial legumes and in $\mathrm{N}_{160} \mathrm{P}_{100}$ fertilization.

In cambic chernozem, on the slope lands from the Moldavian Plain, a good supply in mobile phosphorus of field crops $\left(37-46 \mathrm{mg} \mathrm{kg}^{-1}\right)$ was maintained in annual application of a rate of $\mathrm{N}_{120} \mathrm{P}_{80}$ and a very good supply (69-78) at the rate of $\mathrm{N}_{80} \mathrm{P}_{60}+30 \mathrm{t}$ ha of manure, applied in crops from 3- or 4 -year crop rotations with perennial grasses and legumes (Table 8).

\begin{tabular}{|c|c|c|c|c|c|c|}
\hline Treatment & Mcc & WM & PWM & PWMSf+G & Average & Difference \\
\hline $\mathrm{N}_{0} \mathrm{P}_{0}$ & 13 & 10 & 14 & 15 & 13.0 & 0 \\
\hline $\mathrm{N}_{80} \mathrm{P}_{60}$ & 29 & 26 & 35 & 40 & 32.5 & $19.5^{x \times x}$ \\
\hline $\mathrm{N}_{120} \mathrm{P}_{80}$ & 41 & 38 & 49 & 56 & 46.0 & $33.0^{x \times x}$ \\
\hline $\mathrm{N}_{160} \mathrm{P}_{100}$ & 58 & 52 & 63 & 69 & 60.5 & $47.5^{x \times x}$ \\
\hline $\mathrm{N}_{80} \mathrm{P}_{60}+30$ t.ha- ${ }^{-1}$ manure & 67 & 58 & 69 & 78 & 68.0 & $55.0^{x \times x}$ \\
\hline Average & 41.6 & 36.8 & 46.0 & 51.6 & 44.0 & \\
\hline Difference & 0 & $-4.8^{0}$ & $4.4^{x}$ & $10.0 \times x x$ & & \\
\hline & \multicolumn{2}{|c|}{ Rotation } & \multicolumn{2}{|c|}{ Fertilizer } & \multicolumn{2}{|c|}{ Interaction } \\
\hline LSD 5\% & \multicolumn{2}{|c|}{3.8} & \multicolumn{2}{|c|}{3.3} & \multicolumn{2}{|c|}{$4.3 \mathrm{mg} \cdot \mathrm{kg}^{-1}$} \\
\hline LSD 1\% & \multicolumn{2}{|c|}{5.1} & \multicolumn{2}{|r|}{4.4} & \multicolumn{2}{|c|}{$5.7 \mathrm{mg} \cdot \mathrm{kg}^{-1}$} \\
\hline LSD $0.1 \%$ & \multicolumn{2}{|c|}{6.7} & \multicolumn{2}{|r|}{5.8} & \multicolumn{2}{|c|}{$7.5 \mathrm{mg} \cdot \mathrm{kg}^{-1}$} \\
\hline
\end{tabular}

Table 8. Influence of long-term fertilization and crop rotation on the content of mobile phosphorus from soil (P-AL, mg.kg-1) 
After 43 years of testing, the lowest rate of mobile phosphorus accumulation in soil was recorded in wheat-maize rotation, and the highest one, in 3- and 4- year crop rotations, including annual and perennial legumes, which leave in soil easily degradable crop residues.

\subsection{Influence of tillage practices on yields of maize and wheat and on some soil properties}

Soil is basic medium for seed germination, seed emergence, root growth and ultimately crop production. In the last period, the investigations conducted in different countries followed the influence of improving technological elements on fertilization, soil tillage and crop rotations with legumes and perennial grasses, which determine the increase in the content of organic carbon from soil and the reduction of $\mathrm{N}_{2} \mathrm{O}$ emissions. The $\mathrm{N}_{2} \mathrm{O}$ emissions from soil increase linearly with the amount of mineral nitrogen applied by fertilization $(0.0119 \mathrm{~kg}$ $\mathrm{N}_{2} \mathrm{O}-\mathrm{N}$ ha ${ }^{-1}$ year $\left.^{-1}\right)$. The application of manure determines the diminution in nitrogen protoxide emissions $\left(0.99 \mathrm{~kg} \mathrm{~N}_{2} \mathrm{O}-\mathrm{N} \cdot \mathrm{ha}^{-1}\right.$ year-1 $\left.^{-1}\right)$, compared with the application of liquid

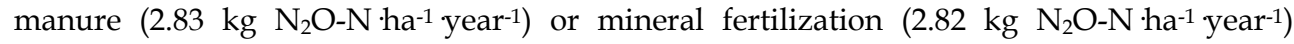
(Gregorich et al., 2005). The conventional system with annual ploughing, carried out at the same depth and with repeated treatments for seedbed preparation with disk-harrows, has negative consequences on soil physical characteristics: mechanical and water stability of aggregates, porosity, infiltration capacity, hydraulic conductivity, water holding capacity, stratification of organic matter and nutrients, activity and diversity of edaphic flora and fauna, carbon biomass, soil water and temperature regime (Jitareanu et al., 2007). Environment deterioration is mainly caused by soil erosion, compaction, soil structure damage due to human activities and loss of organic matter, as well as by extreme climatic conditions, influenced by world changes. Because the farming conventional systems have caused soil degradation in many countries, the technologies concerning the mechanization of agricultural practices must be adapted to the requirements concerning soil and water protection, and in the areas with soils more sensitive to degradation, soil conservation practices are necessary (Flanagan et al., 2009). Soils tilled at time, differentiated according to the requirements of crop rotations, to climatic conditions, contribute to the improvement of soil physicochemical characteristics, to diminish weed infestation degree and allow manure and crop residue incorporation. By diminishing the soil intensity and mobilization depth, the aggregation condition is improved and, therefore, the losses of organic carbon are diminished, as a result of humus decay, due to less aired environment and to better soil protection against erosion (Jug et al., 2007, Romaneckas et al., 2010). The content of organic carbon in the shallow layer $(0-10 \mathrm{~cm})$ on Gleyic Luvisol with sandy loam texture from Halle, Germany, after 37 years of applying different soil tillage systems, differentiated from 10.0 $\mathrm{g} \cdot \mathrm{kg}^{-1}$ under the conventional system, with $25 \mathrm{~cm}$ ploughing, to $14.9 \mathrm{~g} \mathrm{~kg}^{-1}$ at $25 \mathrm{~cm}$ chisel tillage and, respectively, to $13.2 \mathrm{~g} \mathrm{~kg}^{-1}$ under no-tillage. At the depth of $0-20 \mathrm{~cm}$, the content of organic carbon was of $10.2 \mathrm{~g} \mathrm{kg-1}$ at $25 \mathrm{~cm}$ ploughing, $12.7 \mathrm{~g} \mathrm{~kg}^{-1}$ at chisel tillage and 11.6 $\mathrm{g} \mathrm{kg-1}$ under no-tillage. The use of legumes for soil protection against erosion has resulted in fixing $105 \mathrm{~kg}$ from the atmospheric nitrogen and annual increase in the carbon content from soil by $1055 \mathrm{~kg}$, which is twice higher than the accumulation in the no-till system (Farahbakhshazada et al., 2008). In Austria, between 1994 and 2007, the mean soil losses at the three locations dropped from 6.1 to $1.8 \mathrm{t}^{\mathrm{h}} \mathrm{ha}^{-1}$ year-1 with conservation tillage in cover crops, and to $1.0 \mathrm{t}$.ha.year ${ }^{-1}$ with direct drilling. Nitrogen $\left(9.2,3.7,2.5 \mathrm{t}\right.$.ha.year ${ }^{-1}$ ) and 
phosphorus (4.7, 1.3, $0.7 \mathrm{t}^{\mathrm{t}}$ ha.year ${ }^{-1}$ ) losses showed similar tendencies (Colyer, 2005, Ghuman \& Sur, 2001).

The aim was to study the influence of soil tillage systems and fertilization on yield of soybean, wheat and maize crops and soil agrochemical characteristics in long-term field experiments.

The influence of soil tillage systems and fertilization on yield of soybean, wheat and maize crops and soil agrochemical characteristics was studied in field experiments conducted during 1998-2010 on a Cambic Chernozem at the Agricultural Research and Development Station of Podu-Iloaiei, Iasi County.

The typical Cambic Chernozem from Podu-Iloaiei was formed on a loessy loam, has a mean humus content (3.1-3.4\%), is well supplied with mobile potassium (215-235 ppm) and moderately with phosphorus (28-35 ppm) and nitrogen $(0.160-0.165 \%)$. Soil has a high clay content $(39-41 \%)$ being difficult to treat when soil moisture is close to the wilting point $(12.2 \%)$. In wheat, we used Gabriela variety and in maize Oana hybrid.

Experiments were set up in split-split plots with four replicates, tillage treatments in main plots and fertilization in subplot. Tillage treatments were seedbed preparation by $20 \mathrm{~cm}$ ploughing + disking, $30 \mathrm{~cm}$ ploughing + disking, chisel tillage + disking, paraplow tillage and disking and one year ploughing + one year disking. Fertilization treatments were unfertilized $\left(\mathrm{N}_{0} \mathrm{P}_{0}\right), \mathrm{N} 120 \mathrm{~kg}^{-1} \mathrm{ha}^{-1}\left(\mathrm{~N}_{120}\right)+80 \mathrm{~kg}$ ha-1 $\mathrm{P}_{2} \mathrm{O}_{5}\left(\mathrm{P}_{80}\right), \mathrm{N} 160 \mathrm{~kg}^{-1}\left(\mathrm{~N}_{160}\right)+80$ $\mathrm{kg}$ ha ${ }^{-1} \mathrm{P}_{2} \mathrm{O}_{5}, \mathrm{~N} 80 \mathrm{~kg}$ ha-1 $\left(\mathrm{N}_{80}\right)+80 \mathrm{~kg}$ ha- $\mathrm{P}_{2} \mathrm{O}_{5}+30 \mathrm{t}$. ha-1 manure and $\mathrm{N}_{80}+80 \mathrm{~kg}^{-1}$ ha-1 $\mathrm{P}_{2} \mathrm{O}_{5}$ $+6 \mathrm{t} \cdot \mathrm{ha}^{-1}$ wheat straw. In the field there was a 3-year crop rotation (soybean-wheat-maize), Physical and chemical analyses of soil samples were carried out according to the methods established by the Research Institute of Bucharest, which are applied by all agrochemistry laboratories from Romania.

Soil on which physical and chemical analyses were done was sampled at the end of plant growing period. Soil response was determined in water suspension by potentiometric means with glass electrode. The content of organic carbon was determined by the WalkleyBlack method, the content in mobile phosphorus from soil was determined by Egner-RiehmDomingo method, in solution of ammonium acetate-lactate (AL) and potassium was measured in the same extract of acetate-lactate (AL) by flame photometry.

Rainfall during January-June (1998-2010) assured normal conditions for wheat growing in 5 years. Rainfall amounts were lower, compared to the multiannual mean on 80 years (248 $\mathrm{mm}$ ) in 5 years, when rainfall deficit was between 53.3 and $119.0 \mathrm{~mm}$. The climatic conditions during 1998-2010 were favourable to maize growing and development in 5 years and unfavourable, due to low rainfall amounts, in the other 6 years. In the last 13 years, the deficit of rainfall during January-August, compared to the multiannual mean of the area, was between 31.4 and $136.9 \mathrm{~mm}$ in 5 years. The drought in autumn and during JanuaryAugust required the adjustment of soil preparation practices to the requirements of water conservation from soil. Most of soils in the Moldavian Plateau situated on slope fields, poor in organic matter and nutrients, the proper use of different organic resources may replace a part of rich technological consumption (mineral nutrients), determine the improvement in the content of organic matter from soil and may assure better conditions for the capitalization of nitrogen fertilizers.

The mean wheat yields obtained during 1998-2010 at $20 \mathrm{~cm}$ ploughed variant were of 3265 $\mathrm{kg}$ ha ${ }^{-1}$ and in case of seedbed preparation by chisel + disk and by repeated disking, the yields were lower by $4.0 \%\left(122 \mathrm{~kg} \mathrm{ha}^{-1}\right)$ and $6.0 \%(223 \mathrm{~kg}$ ha-1), respectively, as compared to 
$20 \mathrm{~cm}$ ploughing (Table 9). At the same period, the mean wheat yields obtained under unfertilized were of $1818 \mathrm{~kg}$ ha-1 and the rates of $\mathrm{N}_{120}+80 \mathrm{~kg}^{-1} \mathrm{ha}^{-1} \mathrm{P}_{2} \mathrm{O}_{5}$ or $\mathrm{N}_{160}+80 \mathrm{~kg}$ ha ${ }^{-1}$ $\mathrm{P}^{2} \mathrm{O}^{5}$ resulted in getting yield increases of $94 \%\left(1714 \mathrm{~kg} \mathrm{ha}^{-1}\right)$ and $110 \%$ (2006 kg ha-1), respectively. The application in wheat of a rate of $\mathrm{N}_{80}+80 \mathrm{~kg}^{-1} \mathrm{ha}^{-1} \mathrm{P}^{2} \mathrm{O} 5+30 \mathrm{t} \mathrm{ha}^{-1}$ manure resulted in getting yield increases of $117 \%\left(2122 \mathrm{~kg} \mathrm{ha}^{-1}\right)$.

In wheat, found in a 3-year crop rotation (soybean-wheat-maize), the percentage of hydrostable aggregates was less influenced by soil tillage system (54.7-62.8\%) and more by applied fertilizers (50.3-61.3\%) (Table 10).

In wheat crop, the percentage of hydrostable aggregates varied, according to applied fertilizer rates, between 49.2 and $58.6 \%$ at $20 \mathrm{~cm}$ ploughing, between 53.3 and $59.9 \%$ at $30 \mathrm{~cm}$ ploughing and between 56.2 and $68.8 \%$ at chisel treatment. The highest percentage of hydrostable aggregates was at the rate of $\mathrm{N}_{160}+80 \mathrm{~kg} \mathrm{P}_{2} \mathrm{O}_{5}(58.2 \%)$ and at organo-mineral fertilization $(61.3 \%)$.

The content of organic carbon in the shallow layer $(0-20 \mathrm{~cm})$ comprised between 18.43 and $20.08 \mathrm{~g} / \mathrm{kg}$ at the fertilization with $\mathrm{N}_{120}+80 \mathrm{~kg}$ ha- $\mathrm{P}_{2} \mathrm{O}_{5}$ and, respectively, $\mathrm{N}_{80} \mathrm{P}_{80}+30 \mathrm{t}$ ha ${ }^{-1}$ manure (Table 11). At chisel and paraplow works, the content of organic carbon from soil was higher by $0.33 \mathrm{~g} \mathrm{ha}^{-1}$, as compared to $20 \mathrm{~cm}$ ploughing system.

Applying for 13 years moderate mineral fertilizer rates $\left(\mathrm{N}_{80} \mathrm{P}_{80}\right)$, together with $6 \mathrm{~kg} \mathrm{ha}^{-1}$ wheat straw, has resulted in increasing the organic carbon from soil by $1.7 \mathrm{~g}$ ha ${ }^{-1}$, compared to unfertilized variant. The highest content of organic carbon was found at the rate $\mathrm{N}_{80} \mathrm{P}_{80}+30 \mathrm{t} \cdot \mathrm{ha}^{-1}$ manure, where it increased by $2.67 \mathrm{~g} \mathrm{ha}^{-1}$, compared to the unfertilized control.

\begin{tabular}{|c|c|c|c|c|c|c|c|c|}
\hline Soil tillage & $\mathrm{N}_{0} \mathrm{P}_{0}$ & $\begin{array}{l}\mathrm{N}_{80} \mathrm{P}_{80}+6 \text { t.ha- }{ }^{-1} \\
\text { wheat straw }\end{array}$ & $\mathrm{N}_{120} \mathrm{P}_{80}$ & $\mathrm{~N}_{160} \mathrm{P}_{80} \mathrm{t}$ & $\begin{array}{c}\mathrm{N}_{80} \mathrm{P}_{80}+30 \\
\text { t.ha- }{ }^{-1} \text { manure }\end{array}$ & Mean & $\%$ & $\begin{array}{l}\text { Differ. } \\
\text { kg.ha-1 }\end{array}$ \\
\hline $\begin{array}{l}20 \mathrm{~cm} \text { ploughing + } \\
\text { disk }\end{array}$ & 1860 & 2960 & 3520 & 3890 & 4097 & 3265 & 100 & 0 \\
\hline $\begin{array}{l}30 \mathrm{~cm} \text { ploughing + } \\
\text { disk }\end{array}$ & 1950 & 3213 & 3880 & 4232 & 4331 & 3521 & 108 & 256 \\
\hline Chisel + disk & 1870 & 2587 & 3540 & 3840 & 3880 & 3143 & 96 & -122 \\
\hline Paraplow + disk & 1690 & 2823 & 3380 & 3640 & 3620 & 3031 & 93 & -235 \\
\hline $\begin{array}{l}\text { One year ploughing, } \\
\text { one year disking }\end{array}$ & 1720 & 2860 & 3340 & 3520 & 3770 & 3042 & 93 & -223 \\
\hline Mean & 1818 & 2889 & 3532 & 3824 & 3940 & 3201 & & \\
\hline$\%$ & 100 & 159 & 194 & 210 & 217 & & & \\
\hline \multirow[t]{2}{*}{ Difference kg.ha-1 } & 0 & 1071 & 1714 & 2006 & 2122 & & & \\
\hline & \multicolumn{2}{|c|}{ Soil tillage (A) } & Fertilizer (B) & \multicolumn{2}{|c|}{ Interaction $\mathrm{A} \times \mathrm{B}$} & & & \\
\hline LSD 5\% & & 198 & 150 & 330 & & & & \\
\hline LSD 1\% & & 321 & 201 & 481 & & & & \\
\hline LSD $0.1 \%$ & & 516 & 264 & 689 & & & & \\
\hline
\end{tabular}

Table 9. Influence of soil tillage system and fertilization on wheat yield (kg.ha-1). 


\begin{tabular}{|c|c|c|c|c|c|c|c|c|}
\hline \multirow[b]{2}{*}{ Soil tillage } & \multirow{2}{*}{\multicolumn{2}{|c|}{$\mathrm{N}_{0} \mathrm{P}_{0}{ }_{\text {wheat straw }}^{\mathrm{N}_{80} \mathrm{P}_{80}+6 \mathrm{t} \cdot \mathrm{ha}^{-1}}$}} & \multicolumn{6}{|c|}{$\mathrm{N}_{80} \mathrm{P}_{80}+30$ t.ha- } \\
\hline & & & $\mathrm{N}_{120} \mathrm{P}_{80}$ & $\mathrm{~N}_{160} \mathrm{P}_{80}$ & $\begin{array}{c}1 \\
\text { manure }\end{array}$ & Mean & $\%$ & Differ. \\
\hline $\begin{array}{l}20 \mathrm{~cm} \text { ploughing }+ \\
\text { disk }\end{array}$ & 49.2 & 55.2 & 53.1 & 55.2 & 58.6 & 54.7 & 100 & 0.0 \\
\hline $\begin{array}{l}30 \mathrm{~cm} \text { ploughing + } \\
\text { disk }\end{array}$ & 53.3 & 58.3 & 56.8 & 58.3 & 59.9 & 57.5 & 105 & 2.8 \\
\hline Chisel + disk & 56.2 & 65.1 & 61.9 & 65.1 & 68.8 & 62.8 & 115 & 8.1 \\
\hline Paraplow + disk & 51.8 & 59.9 & 57.9 & 59.9 & 64.2 & 58.8 & 108 & 4.1 \\
\hline $\begin{array}{l}\text { One year ploughing, } \\
\text { one year disking }\end{array}$ & 40.9 & 52.4 & 47.3 & 52.4 & 55.2 & 49.6 & 91 & -5.1 \\
\hline Mean & 50.3 & 58.2 & 55.4 & 58.2 & 61.3 & 56.7 & & \\
\hline$\%$ & 100 & 116 & 110 & 116 & 122 & & & \\
\hline \multirow[t]{2}{*}{ Difference } & 0 & 8 & 5 & 8 & 11 & & & \\
\hline & \multicolumn{2}{|c|}{ Soil tillage (A) } & Fertilizer (B) & \multicolumn{2}{|c|}{ Interaction $\mathrm{A} \times \mathrm{B}$} & & & \\
\hline LSD 5\% & & 3.1 & 3.0 & 5.4 & & & & \\
\hline LSD 1\% & & 5.5 & 5.4 & 7.5 & & & & \\
\hline LSD $0.1 \%$ & & 9.3 & 9.1 & 10.3 & & & & \\
\hline
\end{tabular}

Table 10. The influence of soil tillage and fertilization on hydrostability of soil aggregates greater than $0.25 \mathrm{~mm}(\%)$

\begin{tabular}{|c|c|c|c|c|c|c|c|c|}
\hline Soil tillage & $\mathrm{N}_{0} \mathrm{P}_{0}$ & $\begin{array}{c}\mathrm{N}_{80} \mathrm{P}_{80}+6 \\
\text { t.ha-1 } \\
\text { wheat straw }\end{array}$ & $\mathrm{N}_{120} \mathrm{P}_{80}$ & $\begin{array}{c}\mathrm{N}_{160} \mathrm{P}_{8} \\
0\end{array}$ & $\begin{array}{c}\mathrm{N}_{80} \mathrm{P}_{80}+30 \\
\text { t.ha- }{ }^{-1} \\
\text { manure } \\
\end{array}$ & $\begin{array}{c}\text { Mea } \\
\mathrm{n}\end{array}$ & $\%$ & Differ \\
\hline $\begin{array}{l}20 \mathrm{~cm} \text { ploughing + } \\
\text { disk }\end{array}$ & 17.33 & 19.07 & 18.27 & 18.97 & 19.97 & 18.72 & 100 & 0.000 \\
\hline $\begin{array}{l}30 \mathrm{~cm} \text { ploughing + } \\
\text { disk }\end{array}$ & 17.27 & 19.03 & 18.43 & 18.93 & 20.00 & 18.73 & 100 & 0.013 \\
\hline Chisel + disk & 17.67 & 19.33 & 18.73 & 19.23 & 20.53 & 19.10 & 102 & 0.380 \\
\hline Paraplow + disk & 17.80 & 19.33 & 18.73 & 18.97 & 20.40 & 19.05 & 102 & 0.327 \\
\hline $\begin{array}{l}\text { One year ploughing, } \\
\text { one year disking }\end{array}$ & 16.97 & 18.77 & 18.00 & 18.73 & 19.50 & 18.39 & 98 & -0.327 \\
\hline Mean & 17.41 & 19.11 & 18.43 & 18.97 & 20.08 & 18.80 & & \\
\hline$\%$ & 100 & 110 & 106 & 109 & 115 & & & \\
\hline Differ. & 0.00 & 1.70 & 1.03 & 1.56 & 2.67 & & & \\
\hline & Soil & tillage $(\mathrm{A})$ & $\begin{array}{c}\text { Fertilizer } \\
\text { (B) }\end{array}$ & \multicolumn{2}{|c|}{ Interaction $\mathrm{A} \times \mathrm{B}$} & & & \\
\hline LSD 5\% & & 0.351 & 0.341 & \multicolumn{2}{|l|}{0.784} & & & \\
\hline LSD 1\% & & 0.510 & 0.455 & \multicolumn{2}{|l|}{1.080} & & & \\
\hline LSD $0.1 \%$ & & 0.765 & 0.599 & \multicolumn{2}{|l|}{1.487} & & & \\
\hline
\end{tabular}

Table 11. Evolution of the organic carbon content from soil, 10 years after applying different rates of fertilizers and soil tillage systems 
Many investigations conducted in different countries have shown that applying low rates of mineral fertilizers with nitrogen, phosphorus and potassium in wheat and maize continuous cropping and wheat-maize rotation has determined the diminution in the content of organic matter from soil. The diminution in the content of organic carbon from soil, due to mineral fertilization, was found in loam-sandy fields from Nashua, USA, where lower rate than 180 $\mathrm{kg} \mathrm{N}$ ha-1 ${ }^{-1}$ was applied in maize-soybean rotation (Russell et al., 2006) and in clay loam soils from Rothamsted, England, where lower rates than $\mathrm{N}_{192} \mathrm{P}_{35} \mathrm{~K}_{90} \mathrm{Mg}_{35}$ were applied (Blair et al., 2006).

\subsubsection{Long-term effect of nitrogen and phosphorus fertilizer and crop residue on production and soil fertility in the Moldavian Plateau}

In many countries, the investigations conducted on eroded soils have followed the establishment of crop rotations and soil tillage and fertilizing systems, which contribute to maintaining and recovery of soil fertility (Campbell et al., 2005, Yadav \& Malanson, 2008).

The negative impact of continuous cropping on the content of organic carbon from soil was shown by many specialists (Lal, 2006, Liu et al., 2006, Rusu et al., 2006, Wesley et al., 2006). In many areas, applying crop residues, together with moderate nitrogen rates, have resulted in improving physical, chemical and biological soil characteristics (Carter et al., 2002, Naderloo et al., 2009). The investigations conducted on maize by Lindstrom, in Minnesota, USA, show that applying crop residues at rates of 927 and $3706 \mathrm{~kg}^{\text {ha-1 }}{ }^{-1}$ has determined the decrease in soil erosion from 6.18 to $0.99 \mathrm{t} \mathrm{ha}^{-1}$ and in water runoff from 35.6 to $22.9 \mathrm{~mm}$. Other studies show that applying crop residues, together with nitrogen fertilizers, under conventional soil tillage with ploughing, did not result in increasing the organic carbon content after 30 years of experiencing (Osvaldo, 2006). These studies show that establishing the amounts of crop residues, which must be applied for maintaining the content of organic carbon and for diminishing soil erosion, should have in view the interactions between crop rotation, soil tillage, fertilization and soil and climate conditions. The amounts of applied crop residues must contribute to diminishing soil erosion, maintaining the content of organic carbon from soil and determining yield increases.

On weakly eroded lands, the mean maize yields obtained during 1997-2010, were comprised between $3287 \mathrm{~kg}^{-1} \mathrm{ha}^{-1}(100 \%)$ at the unfertilized control and $7188 \mathrm{~kg}^{-1} \mathrm{ha}^{-1}(119 \%)$ at rates of 70 $\mathrm{kg} \mathrm{N}+70 \mathrm{~kg} \mathrm{P} \mathrm{O}_{5}+60 \mathrm{t} \cdot \mathrm{ha}^{-1}$ manure (Table 12). In maize, the application of mean rates of mineral fertilizers $\left(70 \mathrm{~kg} \mathrm{~N}+70 \mathrm{~kg} \mathrm{P}_{2} \mathrm{O}_{5}\right)$ with $60 \mathrm{t}$ ha-1 manure has resulted in getting yield increases of $134 \%$ (3275 kg ha $\left.{ }^{-1}\right)$, compared to the unfertilized variant. Applying rates of 100 $\mathrm{kg} \mathrm{N}+100 \mathrm{~kg} \mathrm{P}^{2} \mathrm{O}^{5}$ resulted in getting yield increases of $84 \%\left(2748 \mathrm{~kg} \mathrm{ha}^{-1}\right)$ in maize, placed on weakly eroded lands, and $94 \%\left(2306 \mathrm{~kg}^{\text {ha }}{ }^{-1}\right)$ in maize placed on highly eroded soil, compared to the unfertilized variant.

In maize placed on weakly eroded lands, the mean yield increases obtained for each $\mathrm{kg}$ of a.i. of applied fertilizers have varied according to applied fertilizers rates, between 7.2 and $14.1 \mathrm{~kg}$ grains $\left(\mathrm{N}_{40} \mathrm{P}_{40}-\mathrm{N}_{140} \mathrm{P}_{100}\right)$. On highly eroded lands, the mean maize yield obtained under unfertilized was of $2452 \mathrm{~kg} \mathrm{ha}^{-1}$, while the mean yield increases, obtained by applying 40 or 60 $\mathrm{t}$. ha-1 manure, were of 36.4-34.2 kg grains per ton of applied manure. The mineral fertilizers $\left(\mathrm{N}_{40} \mathrm{P}_{40}-\mathrm{N}_{140} \mathrm{P}_{100}\right)$ resulted in getting mean yield increases of $8.4-11.7 \mathrm{~kg}$ grains ha ${ }^{-1} \mathrm{a}$. i. of applied fertilizer. Very close yield results were also obtained by applying, for 43 years, rates of $70 \mathrm{~kg} \mathrm{~N}+70 \mathrm{~kg} \mathrm{P} \mathrm{P}_{2} \mathrm{O}_{5} \mathrm{ha}^{-1}+3 \mathrm{t}$ ha-1 stalks of pea or soybean, variants at which yield increases have varied, according to soil erosion, between 2550 and $2615 \mathrm{~kg}^{\text {ha-1 }}$ (78-80\%) on weakly 
eroded lands and between 2161 and $2223 \mathrm{~kg}^{\text {ha-1 }}$ (88-91\%) on highly eroded lands (Table 12). The analysis of results obtained has shown that the erosion process, by decreasing soil fertility, has determined the differentiation of the mean maize yield, according to slope and erosion, from $5756(100 \%)$ to $4538 \mathrm{~kg} \mathrm{ha}^{-1}(78.8 \%)$. Mean annual losses of yields registered in maize in the last 13 years, caused by erosion, were of $1218 \mathrm{~kg}^{\mathrm{ha}} \mathrm{h}^{-1}(21.2 \%)$.

\begin{tabular}{|c|c|c|c|c|c|c|c|c|}
\hline \multirow{3}{*}{ Fertilizer rate } & \multicolumn{4}{|c|}{ Weakly eroded soil } & \multicolumn{4}{|c|}{ Highly eroded soil } \\
\hline & \multicolumn{2}{|c|}{ Maize } & \multicolumn{2}{|c|}{ Wheat } & \multicolumn{2}{|c|}{ Maize } & \multicolumn{2}{|c|}{ Wheat } \\
\hline & yield & diff. & yield & diff. & yield & diff. & yield & diff. \\
\hline $\mathrm{N}_{0} \mathrm{P}_{0}$ & 3287 & 0 & 1697 & 0 & 2452 & 0 & 1163 & 0 \\
\hline $\mathrm{N}_{70} \mathrm{P}_{70}$ & 5159 & 1872 & 3192 & 1495 & 4120 & 1668 & 2478 & 1315 \\
\hline $\mathrm{N}_{100} \mathrm{P}_{100}$ & 6035 & 2748 & 4078 & 2381 & 4758 & 2306 & 3248 & 2085 \\
\hline $\mathrm{N}_{140} \mathrm{P}_{100}$ & 6660 & 3373 & 4523 & 2826 & 5263 & 2811 & 3665 & 2502 \\
\hline $\mathrm{N}_{70} \mathrm{P}_{70} \mathrm{~K}_{70}$ & 5285 & 1998 & 3384 & 1687 & 4251 & 1799 & 2710 & 1547 \\
\hline $\mathrm{N}_{100} \mathrm{P}_{100} \mathrm{~K}_{100}$ & 6324 & 3037 & 4398 & 2701 & 5020 & 2568 & 3570 & 2407 \\
\hline $\mathrm{N}_{140} \mathrm{P}_{100} \mathrm{~K}_{100}$ & 6816 & 3529 & 4797 & 3100 & 5475 & 3023 & 3923 & 2760 \\
\hline $20 \mathrm{t} \cdot \mathrm{ha}^{-1}$ manure & 4150 & 863 & 2761 & 1064 & 3252 & 800 & 2165 & 1002 \\
\hline 40 t.ha- ${ }^{-1}$ manure & 5199 & 1912 & 3445 & 1748 & 3909 & 1457 & 2813 & 1650 \\
\hline 60 t.ha-1 manure & 5953 & 2666 & 4018 & 2321 & 4505 & 2053 & 3294 & 2131 \\
\hline $\mathrm{N}_{70} \mathrm{P}_{70}+20$ t.ha-1 manure & 6119 & 2832 & 4102 & 2405 & 4719 & 2267 & 3304 & 2141 \\
\hline $\mathrm{N}_{70} \mathrm{P}_{70}+40$ t.ha ${ }^{-1}$ manure & 6545 & 3258 & 4619 & 2922 & 5261 & 2809 & 3669 & 2506 \\
\hline $\mathrm{N}_{70} \mathrm{P}_{70}+60$ t.ha ${ }^{-1}$ manure & 7188 & 3901 & 4894 & 3197 & 5727 & 3275 & 4011 & 2848 \\
\hline $\mathrm{N}_{70} \mathrm{P}_{70}+6 \mathrm{t} \cdot \mathrm{ha}^{-1}$ hashed straw & 5733 & 2446 & 3770 & 2073 & 4646 & 2194 & 3041 & 1878 \\
\hline $\mathrm{N}_{70} \mathrm{P}_{70}+6 \mathrm{t} \cdot \mathrm{ha}^{-1}$ stalks of maize & 5656 & 2369 & 3578 & 1881 & 4500 & 2048 & 2929 & 1766 \\
\hline $\mathrm{N}_{70} \mathrm{P}_{70}+3 \mathrm{t} \cdot \mathrm{ha}^{-1}$ stalks of pea & 5902 & 2615 & 4010 & 2313 & 4675 & 2223 & 3237 & 2074 \\
\hline $\mathrm{N}_{70} \mathrm{P}_{70}+3$ thha-1 stalks of soybean & 5837 & 2550 & 3911 & 2214 & 4613 & 2161 & 3164 & 2001 \\
\hline Mean & 5756 & 100 & 3834 & 100 & 4538 & 78.8 & 3081 & 80.4 \\
\hline LSD 5\% & & 315 & & 340 & & 336 & & 310 \\
\hline LSD 1\% & & 444 & & 450 & & 450 & & 430 \\
\hline LSD $0.1 \%$ & & 593 & & 580 & & 605 & & 570 \\
\hline
\end{tabular}

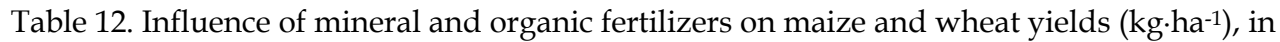
weakly and highly eroded soils, after 43 years of experiments

In wheat, the application of mean rates of mineral fertilizers with $60 \mathrm{t} \cdot \mathrm{ha}^{-1}$ manure has resulted in getting yield increases of $188 \%\left(3197 \mathrm{~kg} \mathrm{ha}^{-1}\right)$, compared to the unfertilized variant. In wheat placed on weakly eroded lands, the mean yield increases obtained for each $\mathrm{kg}$ of a. i. of applied fertilizers varied, according to fertilizers rates applied, between 9.15 and $11.8 \mathrm{~kg}$ grains. The mean annual yield losses, registered in wheat, caused by erosion, were of $753 \mathrm{~kg}$ ha-1 $^{-1}(19.6 \%)$.

The analysis of agro-chemical data shows that nitrogen fertilizers (ammonium nitrate) have determined the $\mathrm{pH}$ decrease. A significant diminution was registered in the ploughed layer, at rates of $140 \mathrm{~kg}$ ha-1 $\mathrm{N}$, where $\mathrm{pH}$ value has reached 5.7, after 43 years (Table 13).

The analyses carried out on the evolution of soil response, after 43 years of experiencing, have shown that the significant diminution in the $\mathrm{pH}$ value was found at higher rates than $100 \mathrm{~kg} \mathrm{~N} \cdot \mathrm{ha}^{-1}$. The lowest $\mathrm{pH}$ values were found in maize at rates of $\mathrm{N}_{140} \mathrm{P}_{100}$ and $70 \mathrm{~kg} \mathrm{~N}+$ $70 \mathrm{~kg} \mathrm{P} \mathrm{P}_{2} \mathrm{O}_{5} \mathrm{ha}^{-1}+6 \mathrm{t}^{\mathrm{h}} \mathrm{h}^{-1}$ stalks of maize, which can be explained by the unfavourable conditions in which the processes of nitrification and crop residue decay, developed. 


\begin{tabular}{|c|c|c|c|c|c|c|c|c|}
\hline \multirow[b]{2}{*}{ Fertilizer rate } & \multicolumn{4}{|c|}{ Weakly eroded lands } & \multicolumn{4}{|c|}{ Highly eroded lands } \\
\hline & $\begin{array}{c}\mathrm{pH} \\
\left(\mathrm{H}_{2} \mathrm{O}\right) \\
\end{array}$ & $\begin{array}{c}\text { Org. C } \\
\mathrm{g} / \mathrm{kg}\end{array}$ & $\begin{array}{l}\mathrm{P}-\mathrm{AL} \\
(\mathrm{ppm})\end{array}$ & $\begin{array}{l}\text { K-AL } \\
(\mathrm{ppm})\end{array}$ & $\begin{array}{c}\mathrm{pH} \\
\left(\mathrm{H}_{2} \mathrm{O}\right)\end{array}$ & $\begin{array}{l}\text { Org. C } \\
\text { g/kg }\end{array}$ & $\begin{array}{l}\text { P-AL } \\
(\mathrm{ppm})\end{array}$ & $\begin{array}{l}\text { K-AL } \\
(\mathrm{ppm})\end{array}$ \\
\hline $\mathrm{N}_{0} \mathrm{P}_{0}$ & 7.3 & 16.5 & 17 & 216 & 7.2 & 14.2 & 8 & 192 \\
\hline $\mathrm{N}_{70} \mathrm{P}_{70}$ & 6.9 & 16.9 & 54 & 186 & 6.8 & 14.3 & 41 & 186 \\
\hline $\mathrm{N}_{100} \mathrm{P}_{80}$ & 6.3 & 17.5 & 86 & 178 & 6.2 & 15.5 & 62 & 174 \\
\hline $\mathrm{N}_{140} \mathrm{P}_{100}$ & 5.8 & 18.2 & 89 & 174 & 5.7 & 16.6 & 64 & 156 \\
\hline $60 \mathrm{t} \cdot \mathrm{ha}^{-1}$ manure & 7.4 & 21.3 & 74 & 276 & 7.1 & 19.9 & 66 & 259 \\
\hline $\mathrm{N}_{70} \mathrm{P}_{70}+60$ t.ha-1 manure & 7.2 & 21.8 & 96 & 292 & 6.9 & 20.2 & 74 & 289 \\
\hline $\begin{array}{l}\mathrm{N}_{70} \mathrm{P}_{70}+6 \mathrm{t} \cdot \text { ha }^{-1} \text { hashed of } \\
\text { wheat }\end{array}$ & 7.0 & 18.9 & 64 & 234 & 6.8 & 18.4 & 57 & 216 \\
\hline $\mathrm{N}_{70} \mathrm{P}_{70}+6 \mathrm{t} \cdot \mathrm{ha}^{-1}$ stalks of maize & 6.6 & 18.8 & 58 & 239 & 6.6 & 18.1 & 52 & 196 \\
\hline $\mathrm{N}_{70} \mathrm{P}_{70}+3 \mathrm{t} \cdot \mathrm{ha}^{-1}$ stalks of pea & 6.9 & 18.5 & 47 & 228 & 6.8 & 18.0 & 48 & 184 \\
\hline $\begin{array}{l}\mathrm{N}_{70} \mathrm{P}_{70}+3 \mathrm{t} \cdot \mathrm{ha}^{-1} \text { stalks of } \\
\text { soybean }\end{array}$ & 6.8 & 18.3 & 51 & 234 & 6.7 & 18.0 & 49 & 182 \\
\hline Mean & 6.8 & 18.7 & 63.6 & 225.7 & 6.7 & 17.3 & 52 & 203 \\
\hline LSD 5\% & 0.27 & 0.07 & 5.9 & 16.1 & 0.24 & 0.10 & 4.8 & 15.7 \\
\hline LSD 1\% & 0.38 & 0.10 & 8.2 & 24.0 & 0.35 & 0.14 & 6.9 & 22.6 \\
\hline LSD $0.1 \%$ & 0.55 & 0.15 & 11.5 & 36.2 & 0.56 & 0.20 & 9.9 & 33.4 \\
\hline
\end{tabular}

Table 13. Effect of soil erosion and fertilization system on the organic carbon and mineral element content in $16 \%$ slope fields

\section{Conclusion}

Mean annual losses of soil by erosion, recorded during 1980-2010, were of $0.25 \mathrm{t} \mathrm{ha}^{-1}$ in perennial grasses in the second growth year, $4.56 \mathrm{t} \mathrm{ha}^{-1}$ in bean, $8.39 \mathrm{t} \mathrm{ha}^{-1}$ in maize and 8.93 $\mathrm{t} \cdot \mathrm{ha}^{-1}$ in sunflower.

Erosion affects soil fertility by removing together with eroded soil, significant mineral element amounts, which in maize and sunflower crops reach $16.2-17.6 \mathrm{~kg}^{-1} \mathrm{a}^{-1}$ nitrogen, 1.2$1.3 \mathrm{~kg}$ ha-1 phosphorus and $2.0-2.4 \mathrm{~kg}$ ha ${ }^{-1}$ potassium, representing, on the average, $12-14 \%$ of the chemical fertilizers necessary for these crops.

On $16 \%$ slope fields, the use of soybean - wheat - maize rotation + two outside fields, cultivated with perennial grasses, determined the diminution by $62.8 \%$ (5.27 $\left.\mathrm{t} \mathrm{ha}^{-1}\right)$ in the mean annual losses of eroded soil and by $59.7 \%\left(9.688 \mathrm{~kg} \mathrm{ha}^{-1}\right)$ in nitrogen leakages, compared with maize continuous cropping.

From the results obtained on erosion in different crop rotations, we found that in $16 \%$ slope fields from the Moldavian Plateau, soil losses by erosion diminished below $4 \mathrm{t}$. ha- $\mathrm{a}^{-1}$ only in case of 3- or 4-year crop rotations with two or three reserve fields, cultivated with legumes and perennial grasses, which protect soil. 
The 43-year use of 4-year crop rotations + reserve field, cultivated with perennial grasses and legumes, has increased soil total carbon $13.4 \%\left(C 2.2 \mathrm{~g} \mathrm{~kg}^{-1}\right)$ in comparison with maize continuous cropping.

Soil preparation without furrow inverting has resulted in improving soil physical and hydro physical characteristics and allowed a better capitalization of technological factors and, especially, of fertilizers, which determined greater yield increases in wheat by $3.6 \%$ (271 $\left.\mathrm{kg} \cdot \mathrm{ha}^{-1}\right)\left(\mathrm{N}_{160}+80 \mathrm{~kg} \cdot \mathrm{ha}^{-1} \mathrm{P}_{2} \mathrm{O}_{5}\right)$, compared to $20 \mathrm{~cm}$ ploughing.

Soil tillage by chisel and disk allowed soil treatment under better conditions for wheat growing in dry autumns, which are very frequent in the area.

The results obtained made us assess that soil tillage system must be adjusted to plant requirements from crop rotation and to soil and climatic conditions of the area. Establishing the systems of soil tillage for the whole crop rotation (disking or chisel + disk work in wheat crop, $20 \mathrm{~cm}$ ploughing for soybean and $25-28 \mathrm{~cm}$ ploughing for maize) resulted in a better capitalization of the other technological factors, water conservation in soil, maintaining soil physical condition and reduction, on the entire rotation cycle, in fuel consumption.

Applying moderate rates of mineral fertilizers $\left(\mathrm{N}_{80} \mathrm{P}_{80}\right)$, together with $6 \mathrm{t}$ ha ${ }^{-1}$ wheat straw or $30 \mathrm{t} \mathrm{ha}^{-1}$ manure, has determined, 10 years after using chisel, the increase in organic carbon content from soil by 1.66 and, respectively, $2.86 \mathrm{~g} \mathrm{~kg}^{-1}$.

On highly eroded lands, in maize after wheat, in a three year rotation, the mean yield obtained under unfertilized was of $2452 \mathrm{~kg}^{-1} \mathrm{ha}^{-1}$, the mean yield increases obtained by applying $60 \mathrm{t} \mathrm{ha-1}$ manure every two years, were of $34.2 \mathrm{~kg}$ grains per ton of manure applied and mineral fertilizers $\left(\mathrm{N}_{140} \mathrm{P}_{100}\right)$ resulted in obtaining mean yield increases of $11.7 \mathrm{~kg}$ grains $\mathrm{kg}-1$ a.i. of applied fertilizer.

On slightly eroded lands, keeping a good supply in soil nutritive elements was done by the annual use of some fertilizer rates of at least $\mathrm{N}_{100} \mathrm{P}_{100}$ or $\mathrm{N}_{70} \mathrm{P}_{70}+40 \mathrm{t}$ ha-1 manure applied once in two years or $\mathrm{N}_{70} \mathrm{P}_{70}+6 \mathrm{t}$ ha- $\mathrm{a}^{-1}$ straw; on highly eroded lands, keeping a good plant supply in mineral elements was done at rates of $\mathrm{N}_{140} \mathrm{P}_{100} \mathrm{~K}_{70}$ or $\mathrm{N}_{70} \mathrm{P}_{70}+40 \mathrm{t}$. ha-1 manure.

\section{Acknowledgment.}

This work was supported by CNCSIS - UEFISCSU, project number PNII - IDEI 1132 / 2008.

\section{References}

Blair, N.; Faulkner, R.D.; Till, A. R. \& Poulton, P. R. (2006). Long-term management impacts on soil C, N and physical fertility. I: Broadbalk experiment. Soil and Tillage Research, Vol. 91, pp. 30-38, ISSN 0167-1987

Bucur, D.; Jitareanu G.; Ailincai C.; Tsadilas C.; Ailincai Despina \& Mercus A. (2007). Influence of soil erosion on water, soil, humus and nutrient losses in different crop systems in the Moldavian Plateau, Romania, Journal of Food, Agriculture $\mathcal{E}$ Environment, Vol. 5, No. 2, pp. 309-312, ISSN 1459-0255

Campbell, C.A.; Janzen, H.H., Paustian, K., Greegorich, E.G., Sherrod, L., Liang, B.C. \& Zentner, R.P. (2005). Carbon storage in soils of the North American Great Plains: Effect of cropping frequency. Agronomy Journal, Vol. 97, pp. 349-363, ISSN 00021962

Carter, M.R.; Saderson, J.B.; Ivany, J.A. \& White, R.P. (2002). Influence of rotation and tillage on forage maize productivity, weed species and soil of a fine sandy loam in the 
humid climate of Atlantic, Canada. Soil and Tillage Research, Vol. 67, pp. 85-98, ISSN 0167-1987

Colyer, D. (2005). Land and agricultural competitiveness. Journal of Food, Agriculture $\mathcal{E}$ Environment. Vol. 7, No. 3\&4, pp.408 - 413, ISSN 1459-0255

Drinkwater, L.E.; Wagoner, P. \& Sarrantonio, M. (1998). Legume-based cropping systems have reduced carbon and nitrogen losses. Nature, Vol. 396, pp. 262-265, ISSN 00280836

Farahbakhshazada, N.; Dinnes, D.L.; Changsheng, L.; Jaynes, D.B. \& Salas, W. (2008). Modeling biogeochemical impacts of alternative management practices for a rowcrop field in Iowa. Agriculture, Ecosystems and Environment, Vol. 123, pp. 30-48, ISSN 0167-8809

Flanagan, D.C.; Gilley J.E. \& Franti T.G. (2009). Water Erosion Prediction Project (WEPP): Development history, model capabilities, and future enhancements. Transactions of the American Society of the Agricultural and Biological Engineers, Vol. 50, No. 5, pp. 1603-1612, ISSN 0001-2351

Ghuman, B.S. \& Sur H.S. (2001). Tillage and residue management effects on soil properties and yields of rainfed maize and wheat in a subhumid subtropical climate. Soil and Tillage Research, Vol. 58, No. 1-2, pp. 1-10, ISSN 0167-1987

Gregorich E.G.; Rochette P.; VandenBygaart A.J. \& Angers D.A. (2005). Greenhouse gas contributions of agricultural soils and potential mitigation practices in Eastern Canada, Soil and Tillage Research, Vol. 83, No. 1, pp. 53-72, ISSN 0167-1987

Izaurralde, R. C.; Williams, J. R.; Post, W. M.; Thomson, A. M.; McGill, W. B.; Owens, L. B. \& Lal, R. (2007). Long-term modeling of soil $C$ erosion and sequestration at the small watershed scale, Climatic Change, Vol. 80, pp. 73-90, ISSN 0165-0009

Jha, M. K.; Schilling, K.E.; Gassman, P.W. \& Wolter, C.F. (2010). Targeting land-use change for nitrate-nitrogen load reductions in an agricultural watershed. Journal of Soil and Water Conservation, Vol. 65, No. 6, pp. 342 - 352, ISSN 0022-4561

Jitareanu G.; Ailincai C. \& Bucur D. (2007). Soil fertility management in North-East Romania, Journal of Food, Agriculture E Environment., Vol. 5, No. 3\&4. pp. 349 - 353, ISSN 1459-0255.

Jug, D.; Stipesevic, B.; Jug, Irena; Samota, D. \& Vukadinovic, V. (2007). Influence of different soil tillage systems on yield of maize. Cereal Research Communications, Vol. 35 , No. 2, pp. 557-560, ISSN 0133-3720

Lal, R. (2006). Enhancing crop yields in developing countries through restoration of the soil organic carbon pool in agricultural lands, Land Degradation and Development, Vol. 17, pp. 197-209, ISSN 1099-145X

Li, B.; Wei, M.; Shen, A.; Xu, J.; Zhang, H. \& Hao, F. (2009). Changes of yields, soil properties and micronutrients as affected by 17-yr fertilization treatments. Journal of Food, Agriculture E Environment. Vol. 7, No. 3\&4, pp. 408 - 413, ISSN 1459-0255

Lindstrom, M. J. (1986). Effects of residue harvesting on water runoff, soil erosion and nutrient loss. Agriculture, Ecosystems and Environment, Vol. 16, pp. 103-112, ISSN 0167-8809

Liu, X.; Herbert, S.J.; Hashemi, A.M.; Zhang, X. \& Ding, G. (2006). Effects of agricultural management on soil organic matter and carbon transformation - a review, Plant Soil Environment, Vol. 52, No. 12, pp. 531-543, ISSN 1214-1178

Marchetti, A.; Piccini, C.; Francaviglia, R.; Santucii, S. \& Chiuchiarelli, I. (2008). Spatial distribution of organic matter to assess soil quality: A case study in Central Italy, Proceedings of CIHEAM 5th International Conference on Land Degradation, pp. 169-173, ISBN 2-85352-399-2, Valenzaro, Bari, Italy, Sept. 18-22, 2008. 
Moraru, Paul Ioana \& Rusu, T. (2010). Soil tillage conservation and its effect on soil organic matter, water management and carbon sequestration, Journal of Food, Agriculture $\mathcal{E}$ Environment. Vol. 8, No. 3\&4, pp. 309 - 312, ISSN 1459-0225.

Muukkonen, P.; Hartikainen, H.; Lahti, K.; Sarkela, A.; Puustinen, M. \& Alakukku, L. (2007). Influence of no-tillage on the distribution and lability of phosphorus in Finnish clay soils, Agriculture, Ecosystems \& Environment, Vol. 120, pp. 299-306, ISSN 01678809.

Naderloo, L.: Alimadani, R.; Akram, A.; Javadikia, P. \& Khanghah, H. (2009). Tillage depth and forward speed effects on draft of three primary tillage implements in clay loam soil. Journal of Food, Agriculture E Environment. Vol. 7, No. 3\&4, pp. 382 - 385, ISSN 1459-0255.

Oswaldo, E. (2006). Soil organic carbon and total nitrogen in relation to tillage and croppasture rotation, Advances in Geoecology, Catena. Vol. 38, pp. 502 - 507, ISBN 3923381-52-2, Reiskirchen, Germany

Pimentel, D.; Harvey, C.; Resosudarmo, P.; Syinclair, K.; Kurz, D.; McNair, M.; Crist, S.; Shpritz, L.; Fitton, L.; Saffouri, R. \& Blair, R. (1995). Environmental and economic costs of soil erosion and conservation benefits. Science, Vol. 267, No. 24, pp. 11171122, ISSN 0036-8075

Popa, A.; Stoian G.; Popa Greta \& Ouatu, O. (1984). Soil erosion control on arable land, Ceres, Bucuresti, Romania

Romaneckas K.; Sarauskis E.; Pilipavicius V.; Adamavicienė Aida \& Avizienyte D. (2010). Impact of primary soil tillage intensity on maize (Zea mays L.) seedbed formation and productivity parameters. Journal of Food, Agriculture E Environment, Vol. 8, No. 3\&4, pp. 679 - 682, ISSN 1459-0255.

Rosner, J.; Zwatz, E.;, Klik, A. \& Gyuricza, C. (2008). Conservation Tillage Systems - Soil Nutrient - and Herbicide Loss in Lower Austria and the Mycotoxin Problem, Proceedings of ISCO 15th International Congress, pp. 205-210, ISBN 978963 9545, Budapest, Hungary, May 18-23, 2010.

Rusu, T.; Gus, P.; Bogdan, Ileana; Moraru, Paula Ioana; Pop, A. I.; Clapa, Doina; Marin, D. I.; Oroian, I. \& Pop, Lavinia. (2009). Implications of minimum tillage systems on sustainability of agricultural production and soil conservation, Journal of Food, Agriculture E Environment, Vol. 7, No. 2, pp. 335 - 338, ISSN 1459-0255.

Russell, A. E., Laird, D. A., Mallarino, A. P. (2006). Nitrogen Fertilization and Cropping System Impact on Quality in Midwestern Mollisols, Soil Sciences Society American Journal, Vol. 70, pp. 249-255, ISSN 0361-5995

Selby, M.J. (1993). Hillslope Materials and Processes. Second edition, Oxford University Press, ISBN 0198741839, Oxford, England

Sial, R.A.; Chuadhary, E.H.; Hussain, S. \& Naveed, M. (2007). Effect of organic manures and chemical fertilizers on grain yield of maize in rainfed area. Soil and Environment, Vol. 26, No. 2, pp. 130-133, ISSN 1019-729X

Totka, M.: Rousseva, S. \& Tzvetkova, E. (2006). Conservation Agricultural Practices for Soil Erosion Protection in Bulgaria - A Brief Review, Advances in Geoecology, Catena. Vol. 38, pp. 1053 - 1059, ISBN 3-923381-52-2, Reiskirchen, Germany

Wesley, R.A.; Elmore, C.D. \& Spurlock, S.R. (2001) Deep tillage and crop rotation effects on cotton, soybean and grain sorghum clayey soils. Agronomy Journal, Vol. 93, pp. 170178, ISSN 0002-1962

Yadav, V. \& Malanson, G. (2008) Spatially explicit historical land use land cover and soil organic carbon transformations in Southern Illinois. Agriculture, Ecosystems and Environment, Vol. 123, pp. 280-292. ISSN 0167-8809 


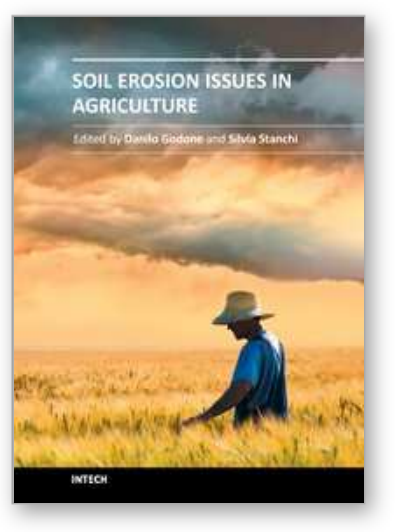

\author{
Soil Erosion Issues in Agriculture \\ Edited by Dr. Danilo Godone
}

ISBN 978-953-307-435-1

Hard cover, 334 pages

Publisher InTech

Published online 21, October, 2011

Published in print edition October, 2011

The book deals with several aspects of soil erosion, focusing on its connection with the agricultural world. Chaptersâ€ $€^{\mathrm{TM}}$ topics are various, ranging from irrigation practices to soil nutrient, land use changes or tillage methodologies. The book is subdivided into fourteen chapters, sorted in four sections, grouping different facets of the topic: introductive case studies, erosion management in vineyards, soil erosion issue in dry environments, and erosion control practices. Certainly, due to the extent of the subject, the book is not a comprehensive collection of soil erosion studies, but it aims to supply a sound set of scientific works, concerning the topic. It analyzes different facets of the issue, with various methodologies, and offers a wide series of case studies, solutions, practices, or suggestions to properly face soil erosion and, moreover, may provide new ideas and starting points for future researches.

\title{
How to reference
}

In order to correctly reference this scholarly work, feel free to copy and paste the following:

Bucur Daniel, Jitareanu Gerard and Ailincai Costica (2011). Soil Erosion Control on Arable Lands from NorthEast Romania, Soil Erosion Issues in Agriculture, Dr. Danilo Godone (Ed.), ISBN: 978-953-307-435-1, InTech, Available from: http://www.intechopen.com/books/soil-erosion-issues-in-agriculture/soil-erosion-control-onarable-lands-from-north-east-romania

\section{INTECH}

open science | open minds

\author{
InTech Europe \\ University Campus STeP Ri \\ Slavka Krautzeka 83/A \\ 51000 Rijeka, Croatia \\ Phone: +385 (51) 770447 \\ Fax: +385 (51) 686166 \\ www.intechopen.com
}

\author{
InTech China \\ Unit 405, Office Block, Hotel Equatorial Shanghai \\ No.65, Yan An Road (West), Shanghai, 200040, China \\ 中国上海市延安西路65号上海国际贵都大饭店办公楼405单元 \\ Phone: +86-21-62489820 \\ Fax: +86-21-62489821
}


(C) 2011 The Author(s). Licensee IntechOpen. This is an open access article distributed under the terms of the Creative Commons Attribution 3.0 License, which permits unrestricted use, distribution, and reproduction in any medium, provided the original work is properly cited. 